\title{
First report of Olpidium virulentus, 0 . bornovanus, 0 . brassicae on cucumber in Sardinia, Italy
}

\author{
Nicola Schianchi ${ }^{1} \cdot$ Safa Oufensou ${ }^{1} \cdot$ Giampiera Porqueddu $^{1} \cdot$ Gabriele Chilosi $^{2} \cdot$ Virgilio Balmas $^{1}$
}

Received: 16 December 2019 / Accepted: 24 June 2020 / Published online: 8 July 2020

(C) Società Italiana di Patologia Vegetale (S.I.Pa.V.) 2020

Keywords Olpidium spp. · Root rot $\cdot$ Cucumber

In the summer of 2019, in an area in North-Sardinia near Alghero, the cultivation of cucumber (Cucumis sativus L.) was subjected to significant losses in yield and quality due to the spread of symptoms represented by root rot and vine decline. Similar symptoms had been observed on watermelon in Sardinia (Italy) in 2018, by two different species of Olpidium: O. virulentus and O. bornovanus (Sahtiyanci) Karling (Schianchi et al. 2019). In the infected area (around $2000 \mathrm{~m}^{2}$ ) almost $60 \%$ of the plants showed collapse's symptoms. Five symptomatic plants of cucumber (cv. Marketmore) were sampled in order to identify the causal agent. The roots section were disinfected with $2 \%$ of sodium hypochlorite and rinsed several times before placing them on Potato Dextrose Agar (PDA) and Water Agar (WA).

After 1 week of incubation at $25^{\circ} \mathrm{C}$, Rhizoctonia sp. and Macrophomina phaseolina were identified from PDA plates, while resting spores of Olpidium spp. were identified from roots section cut with scalpel and grown on WA. Pathogenicity test was conducted with the baiting technique by growing cucumber plants in soils collected near the roots of symptomatic plants and in a sterilized soil, used as a negative control. Plants grown in infested soil showed roots browning, foliage chlorosis followed by plant wilt after 40 days. Twelve plants were used in each thesis. Baited roots were analysed directly under microscope for the presence of Olpidium spp. by using morphological identification methods. Stellate

Nicola Schianchi

nschianchi@uniss.it

1 Dipartimento di Agraria, Sezione di Patologia Vegetale ed Entomologia, Università degli Studi di Sassari, Viale Italia 3907100 Sassari Italy

2 Dipartimento per l'Innovazione nei Sistemi Biologici, Agroalimentari e Forestali, Università degli Studi della Tuscia, Via S. Camillo de Lellis 01100 Viterbo Italy resting spores referred to as $O$. virulentus and smooth-walled resting spores referred to as $O$. bornovanus were observed in diseased roots. Neither disease symptoms nor Olpidium spores were observed from the plants grown in sterilized soil. For molecular analysis, DNA was extracted from cucumber roots, following the protocol described by Aljanabi and Martinez (1997) and tested by multiplex PCR, using specific primers, in order to confirm the presence of Olpidium spp. as described by Herrera-Vásquez et al. (2009). PCR amplification products, corresponding to O. bornovanus (977 bp), $O$. virulentus (579 bp) and $O$. brassicae (204 bp), were detected. To our knowledge, this is the first report of $O$. bornovanus, $O$. virulentus and $O$. brassicae occurrence on cucumber in Italy.

\section{References}

Aljanabi SM, Martinez I (1997) Universal and rapid salt-extraction of high quality genomic DNA for PCR-based techniques. Nucleic Acids Res 25: 4692-4693

Herrera-Vásquez J, del Carmen Cebrián M, Alfaro-Fernández A, del Carmen Córdoba M, Jordá C (2009) Multiplex PCR assay for simultaneous detection and differentiation of Olpidium bornovanus, $O$. brassicae and O. virulentus. Mycol Res 113:602-610

Schianchi N, Oggiano L, Chilosi G, Balmas V (2019) First report of Olpidium bornovanus and O. virulentus on watermelon in Sardinia, Italy. J Plant Pathol 101:1253

Publisher's note Springer Nature remains neutral with regard to jurisdictional claims in published maps and institutional affiliations. 